\title{
Penerapan Sanksi Denda pada Pembiayaan Bai' Bitsaman Ajil di Baitul Maal Wat Tamwil (BMT) Pahlawan Tulungagung atas Keterlambatan dalam Pembayaran Angsuran
}

\author{
Fatkhur Rohman Albanjari ${ }^{1}$, Rokhmat Subagyo ${ }^{2}$ \\ Fakultas Ekonomi dan Bisnis Islam, IAIN Tulungagung \\ fatkhurrrohmanalbanjari@gmail.com ${ }^{1}$, Mat79.eca@gmail.com²
}

\begin{abstract}
This research aims to know us applying sanctions and penalty on financing ' bai bitsaman ajil at the BMT Pahlawan Tulungagung for the delay in payment of the installments. The author's methods of research conducted in this study using a qualitative approach. As for the type of research is descriptive, meaning that the data collected is in the form of words, images, and not the numbers. The results showed that the application of fines in BMT Pahlawan Tulungagung is in compliance with the Shariah Board Fatwa of the national assemblies of scholars of Indonesia No. 17/DSN-MUI/IX/2000. In its application of fines charged to borrowers who can afford but procrastinate the payout as well as clients who do not have good faith to settle the payment.
\end{abstract}

Keywords: Penalty, Baitul Maal Wat Tamwil, Bai Bitsaman Ajil

\begin{abstract}
Abstrak
Penelitian ini bertujuan untuk mengatahui penerapan sanksi denda pada pembiayaan bai' bitsaman ajil di BMT Pahlawan Tulungagung atas keterlambatan dalam pembayaran angsuran. Metode penelitian yang dilakukan penulis dalam penelitian ini menggunakan pendekatan kualitatif.Adapun jenis penelitiannya adalah deskriptif, artinya bahwa data yang dikumpulkan adalah berupa kata-kata, gambar, dan bukan angka-angka. Hasil penelitian menunjukkan bahwa penerapan denda di BMT Pahlawan Tulungagung sudah sesuai dengan Fatwa Dewan Syariah Nasional Majelis Ulama Indonesia NO. 17/DSN-MUI/IX/2000. Dalam penerapannya denda dikenakan kepada nasabah yang mampu akan tetapi menunda-nunda pembayarannya serta nasabah yang tidak memiliki itikad baik untuk melunasi pembayaran.
\end{abstract}

Kata Kunci: Denda, Baitul Maal Wat Tamwil, Bai’ Bitsaman Ajil

\begin{tabular}{lcl}
\hline Permalink/DOI & $:$ & http://dx.doi.org/10.32503/jmk.v4i3.595 \\
Cara Mengutip & $:$ Albanjari, Fatkhur R. \& Subagyo, Rokhmat. (2019). Penerapan \\
& Sanksi Denda pada Pembiayaan Bai' Bitsaman Ajil di Baitul \\
& Maal Wat Tamwil (BMT) Pahlawan Tulungagung atas \\
& Keterlambatan dalam Pembayaran Angsuran. JMK (Jurnal \\
& Manajemen dan Kewirausahaan), 4 (3), 221-230 doi: \\
& http://dx.doi.org/10.32503/jmk.v4i3.595 \\
Sejarah Artikel & $: \begin{array}{l}\text { Artikel diterima 24 Agustus 2019; direvisi 4 September 2019; } \\
\text { disetujui 10 September 2019 }\end{array}$ \\
\hline
\end{tabular}

Alamat korespondensi :

Jl. Mayor Sujadi No.46 Kudusan, Plosokandang, Kec. Kedungwaru

IAIN Tulungagung

Tulungagung, Jawa Timur 


\section{Pendahuluan}

Lembaga keuangan syariah (LKS) pada era millenial ini telah berkembang sangat pesat. Telah banyak variasi lembaga keuangan syariah yang berdiri di Indonesia, seperti Bank Syariah, Bank Perkreditan Rakyat Syariah, Koperasi Syariah dan Baitul Maal Wat Tamwil $(\mathrm{BMT})$, dll. Perkembangan yang sangat

Baitul Maal Wat Tamwil memiliki dua istilah yakni Baitul Maal dan Baitul Tamwil. Baitul maal lebih mengarah pada usaha-usaha penyaluran dana non profit seperti zakat, infaq, sedekah dan wakaf. Sedangkan baitul tamwil merupakan kegiatan yang mengarah kepada usaha-usaha pengumpulan dan penyaluran dana yang bersifat profit dengan memakai sistem profit and loss sharing. Jadi BMT merupakan balai mandiri terpadu yang berintikan bayt al maal wa at-tamwil dengan kegiatan mengembangkan usahausaha produktif dan investasi dalam meningkatkan kualitas pengusaha kecil untuk menunjang pembiayaan dalam kegiaan ekonomi serta dapat menerima titipan zakat, infaq, sedekah dan wakaf (Djazuli, 2002).

Terkait dengan operasional baitul tamwil, BMT memiliki dua produk yakni pengumpulan dana dan penyaluran dana. Kedua produk tersebut, BMT memiliki dua jenis dana yang dapat menunjang kegiatan operasinya, yaitu dana bisnis sebagai input dana yang dapat ditarik kembali oleh pemiliknya setra dana ibadah sebagai input dana yang tidak dapat ditarik kembali oleh pemilik kecuali input dana untuk pinjaman. (Syamsuir, 2017)

Penggunaan akad jual beli dalam penyaluran dana di BMT memiliki perbedaan dengan bank syariah. Produk penyaluran dana di Bank Syariah dikenal saat ini menggunakan istilah akad murabahah yang mana didalamnya menggunakan mekanisme pembayaran bai' bitsaman ajil. Sedangkan pada BMT, mereka menggunakan dua akad tersebut secara terpisah, sehingga BMT memiliki dua macam akad pada produk pembiayaan yakni pembiayaan jual beli murabahah dan pembiayaan bai bitsaman ajil. Karim mengungkapkan bahwa murabahah sama dengan bai' bitsaman ajil, beliau mengatakan bahwa sebenarnya produk pembiayaan al-bai albitsamanil aji secara fiqh adalah albai' al-bitsamanil ajil yang murabahah (Karim, 2001).

Dalam penyaluran dana setiap lembaga keuangan adanya keterlambatan membayar angsurananggota/nasabah sering terjadi. Adanya biaya atas keterlambatan pembayaran atau denda pada pemberian fasilitas pembiayaan dinilai masih sangat memberatkan calon nasabah. Ketentuan biaya tersebut ditentukan besarannya oleh pihak lembaga keuangan yang meliputi nilai nominalnya serta cara penghitungannya. Penetapan biaya atas keterlambatan pembayaran angsuran atau denda adalah sebagai salah satu syarat yang harus disetujui oleh calon nasabah dalam proses pemberian fasilitas pembiayaan.

Adanya penerapan biaya atas keterlambatan pembayaran angsuran atau denda ini sudah diberikan Fatwa oleh Dewan Syariah Nasional NO:17/DSN-MUI/IX/2000 tentang Sanksi Atas Nasabah Mampu Yang Menunda-Nunda Pembayaran. Dalam Fatwa Dewan Syariah Nasional tersebut, nasabah boleh dikenakan sanksi hanya kepada nasabah mampu 
yang menunda-nunda pembayaran dan/atau tidak mempunyai kemauan dan itikad baik untuk membayar hutangnya. Dalam pembiayaan bai' bitsaman ajil pada BMT Pahlawan, ketentuan pemberian sanksi ini diberlakukan kepada nasabah yang tidak mempunyai itikad baik membayar, akan tetapi untuk nasabah yang mengalami keterlambatan membayar tetapi miliki itikad yang baik untuk membayar, memberikan kepastian pembayaran tidak dikenakan denda.

BMT Pahlawan Tulungagung merupakan salah satu dari 5000 BMT yang bertebaran diseluruh tanah air. BMT PAHLAWAN hadir untuk memberdayakan ekonomi masyarakat kecil sesuai syariah Islam, yakni sistem bagi hasil. BMT PAHLAWAN beroperasi sejak 10 Nopember 1996, diresmikan oleh Bapak Bupati Tulungagung dengan disaksikan oleh seluruh unsur MUSPIDA dan para tokoh masyarakat di Tulungagung. Dengan demikian sejak 10 November 1996 BMT PAHLAWAN mulai bergerak membantu para pengusaha kecil yang ada disekitarnya (laporan RAT BMT Pahlawan, 2018).

Keunikan penerapan atas biaya keterlambatan pembayaran angsuran atau denda dalam BMT Pahlawan Tulungagung ini adalah setiap anggota/nasabah yang mendapatkan denda diperbolehkan untuk menawar besaran denda yang dikeluarkan, denda yang dikeluarkan $0,2 \%$ perhari tersebut akan dihapuskan jika nasabah sudah memiliki itikad baik untuk membayarnya, denda yang diberikan kepada nasabah akan hilang/dihapuskan oleh BMT apabila nasabah berjanji untuk melunasi tunggakannya dan akan muncul kembali saat nasabah mengalami penundaan pembayaran yang disengaja.

Prosentase perhitungan denda tersebut dimunculkan saat pembacaan akad di BMT Pahlawan Tulungagung berlangsung, perhitungan denda tersebut terdapat dalam pasal 4 Perjanjian Pembiayaan.

Berdasarkan pemaparan yang telah diuraikan oleh penulis diatas, artikel ini hendak membahas mengenai bagaimanakah penerapan biaya atas keterlambatan pembayaran atau denda dalam pembiayaan bai' bitsaman ajil pada BMT Pahlawan Tulungagung.

\section{Tinjauan Pustaka}

\section{Pengertian Denda}

Denda dalam kamus besar bahasa Indonesia diartikan dengan hukuman berupa membayar sejumlah uang apabila lalai dalam membayar kewajibannya (Yandianto, 2001). Bahasa inggris menyebutkan kata fine yang berarti denda keterlambatan. Sedangkan bahasa arab menyebutkan dengan kata ta'zir atau ta'widh yang berarti ganti rugi terhadap biaya-biaya yang dikeluarkan akibat seorang nasabah terlambat membayar kewajibannya setelah jatuh tempo. (Munawwir, 1987).

Menurut Wahbah Al-Zuhaili dalam kitab Al-Fiqh Al-Islami wa Adillatuh, sanksi-sanksi ta'zir adalah hukum-hukuman yang secara syara' tidak ditegaskan mengenai ukurannya. Syariat Islam menyerahkannya kepada penguasa negara untuk menentukan sanksi terhadap pelaku tindak pidana yang sesaui dengan kejahatannya. Selain itu menumpas permusuhan, mewujudkan situasi aman terkendali dan perbaikan, serta melindungi masyarakat kapan saja dan di mana saja. Sanksi-sanksi ta'zir ini sangat 
beragam sesuai dengan situasi dan kondisi masyarakat, taraf pendidikan masyarakat, dan berbagai keadaan lain manusia dalam berbagai masa dan tempat (Irfan \& Masyofah, 2013).

Pada dasarnya ta'zir tidak ditentukan secara langsung oleh Alquran dan hadis, maka ini menjadi kompetensi penguasa setempat. Dalam memutuskan jenis dan ukuran sanksi ta'zir, harus tetap memberikan petunjuk nash secara teliti karena menyangkut kemaslahatan umum (Irfan \& Masyofah, 2013).

\section{Tujuan dan Syarat Denda}

Munurut Irfan dan Masyofah dengan diberlakukannya sanksi ta'zir, yaitu sebagai berikut:

a. Preventif (pencegahan). Ditujukan bagi orang lain yang belum melakukan jarimah.

b. Represif (membuat pelaku jera). Dimaksudkan agar pelaku tidak mengulangi perbuatan jarimah di kemudian hari.

c. Kuratif. Ta'zir harus mampu membawa perbaikan perilaku terpidana di kemudian hari.

d. Edukatif (pendidikan). Diharapkan dapat mengubah pola hidupnya ke arah yang lebih baik.

Syara' tidak menentukan macam-macam hukuman untuk setiap jarimah ta'zir, tetapi menyebutkan sekumpulan hukuman, dari yang paling ringan sampai yang paling berat. Hakim diberi kebebasan untuk memilih hukuman mana yang sesuai. Dengan demikian, sanksi ta'zir tidak mempunyai batas tertentu (Irfan \& Masyofah, 2013).

Ta'zir berlaku atas semua orang yang melakukan kejahatan. Syaratnya adalah berakal sehat. Tidak ada perbedaan, baik laki-laki maupun perempuan, dewasa maupun anakanak, atau kafir maupun muslim. Setiap orang yang melakukan kemungkaran atau mengganggu pihak lain dengan alasan yang tidak dibenarkan, baik dengan perbuatan, ucapan, atau isyarat, perlu diberi sanksi ta'zir agar tidak mengulangi perbuatannya (Irfan \& Masyofah, 2013).

\section{Metodologi Penelitian}

Metode penelitian yang dilakukan penulis dalam penelitian ini menggunakan pendekatan kualitatif. Penelitian kualitatif ialah prosedur penelitian yang menghasilkan data deskriptif berupa kata-kata tertulis atau lisan serta perilaku dari orang yang diamati (Moleong, 1998). Adapun jenis penelitiannya adalah deskriptif, artinya bahwa data yang dikumpulkan adalah berupa kata-kata, gambar, dan bukan angka-angka.

Instrumen yang digunakan dalam penelitian ini berdasarkan pada karakteristik penelitian kualitatif, yaitu manusia sebagai instrumennya yakni pimpinan dan karyawan BMT Pahlawan. Dalam proses pengumpulan data peneliti menggunakan tehnik wawancara, observasi, dan dokumentasi. Adapun tahap-tahap lapangan penelitian yang peneliti lalui adalah: tahap pra lapangan, tahap pekerjaan lapangan, tahap analisis data (Basrowi \& Suwandi, 2008). Sedangkan pengecekan keabsahan data yang digunakan adalah peneliti menggunakan triangulasi sumber yaitu hasil penelitian yang didapat dari narasumber. Triangulasi sumber adalah suatu cara untuk mengecek 
derajat kepercayaan suatu informasi yang diperoleh melalui alat yang berbeda dalam penelitian kualitatif (Moleong, 1998).

\section{Hasil \& Pembahasan}

Banyak nasabah yang memerlukan pembiayaan dari LKS yang pembayarannya dilakukan secara angsuran. Seringkali nasabah mampu terkadang menunda-nunda kewajiban pembayaran, baik dalam akad jual beli maupun akad yang lain, waktu yang telah ditentukan berdasarkan kesepakatan di antara kedua belah pihak. Begitu juga dalam BMT Pahlawan Tulungagung, banyaknya nasabah yang mampu namun menunda-nunda pembayaran sehingga BMT membuat kebijakan memberikan denda kepada anggotanya.

Pelaksanaan denda BMT Pahlawan yang dikenakan kepada seluruh anggotanya adalah sebesar $0.2 \%$ perhari dari saldo tunggakan. Banyaknyapihak LKS meminta fatwa kepada Dewan Syariah Nasional (DSN) tentang tindakan atau sanksi apakah yang dapat dilakukan terhadap nasabah mampu yang menunda-nunda pembayaran tersebut menurut syari'ah Islam. Oleh karena itu, DSN perlu menetapkan fatwa tentang sanksi atas nasabah mampu yang menunda-nunda pembayaran menurut prinsip syari'ah Islam, untuk dijadikan pedoman oleh lembaga keuangan syariah, khususnya BMT Pahlawan (Sam, 2003).

Untuk perhitungannya yakni saldo tunggakan dikalikan dengan $0.2 \%$ dikali dengan 30 hari maka akan ketemu denda perbulannya. Untuk menghindari hal-hal yang tidak diinginkan dalam pembayaran dan pelunasan hutang pembiayaan maka DSN - MUI mengeluarkan fatwa nomor 17 tahun 2000 tentang sanksi atas nasabah mampu yang menundanunda pembayaran. Adapaun bunyi fatwa sebagai berikut:

1. Sanksi yang disebut dalam fatwa ini adalah sanksi yang dikenakan LKS kepada nasabah yang mampu membayar, tetapi menundanunda pembayaran dengan disengaja.

Dalam praktinya BMT Pahlawan akan memberikan denda kepada nasabah yang mampu membayar akan tetapi menunda-nunda pembayaran. Tidak semua nasabah/anggota dikenakan denda, hanyalah orang-orang tertentu saja. BMT akan memberikan kelonggaran dalam permbayaran denda tersebut dan dilakukan secara tawar menawar tanpa adanya paksaan. Pembayaraan denda tersebut dilihat dari kapasitas/capasity nasabah juga.

2. Nasabah yang tidak/belum mampu membayar disebabkan force majeur tidak boleh dikenakan sanksi.

Tidak semua nasabah BMT dikenakan sanksi keterlambatan. Banyak sekali nasabah yang menunda pembayaran bahkan juga sudah mengalami jatuh tempo tidak dikenakan denda. Hal ini dikarenakan nasabah yang masih memiliki keinginan untuk membayar angsuran. Nasabah yang menunggak yang menjanjikan tanggal pembayaran jugga tidak dikenakan denda oleh BMT Pahlawan. selain itu, nasabah yang mengalami kebangkrutan usaha juga tidak akan diberikan denda oleh BMT Pahlawan. 
3. Nasabah mampu yang menunda-nunda pembayaran dan/atau tidak mempunyai kemauan dan itikad baik untuk membayar hutangnya boleh dikenakan sanksi.

BMT Pahlawan akan memberikan sanksi denda kepada nasabah yang tidak memiliki itikad baik, nasabah yang sulit untuk diajak negosiasi akan dikenakan denda. Hal ini dikarenakan nasabah yang sudah menciderai janji yang telah disepakati diawal. Sebelumnya BMT akan memberikan surat tagihan, surat peringatan, dan melakukan silaturahmi serta penagihan secara intens, kepada nasabah. BMT Pahlawan akan memberikan kelonggaran dalam jangka waktu dan jumlah pembayaran angsuran. BMT Pahlawan tidak akan langsung memberikan denda kepada nasabah.

4. Sanksi didasarkan pada prinsip ta'zir, yaitu bertujuan agar nasabah lebih disiplin dalam melaksanakan kewajibannya.

BMT Pahlawan memberikan sanksi denda ini bertujuan untuk kedisiplinan nasabah membayar angsuran. Akan tetapi banyak nasabah yang tidak mau membayar denda tersebut. BMT Pahlawan tidak memaksa atas denda yang telah diberikan kepada nasabah. Menurut Pimpinan BMT, Denda yang muncul dalam surat peringatan dan tagihan tersebut tidak akan langsung dikenakan kepada nasabah harus ada kesepakatan kedua belah pihak. Bahkan nasabah tidak harus membayar denda sesuai dengan nominal yang tertera dalam surat tersebut. Dana yang tertera dalam surat bisa dihapuskan apabila nasabah memiliki itikad yang baik membayar dan kejelasan dalam tanggal pembayaran, denda akan dimunculkan kembali saat nasabah tersebut lalai kembali dalam membayar kewajiban angsuran.

5. Sanksi dapat berupa denda sejumlah uang yang besarnya ditentukan atas dasar kesepakatan dan dibuat saat akad ditandatangani.

Pada akad Perjanjian BMT Pahlawan Tulungagung pasal 4 menyebutkan bahwa Apabila angsuran lewat dari tanggal tersebut tanpa alasan yang jelas, maka pihak kedua (nasabah) bersedia membayar ta'jir (hukuman) berupa denda $(0.2 \%$ per hari dari saldo tunggakan) untuk disalurkan ke Baitul Maal bagi kepentingan kaum dhuafa. Jika terjadi penagihan maka biaya penagihan yang muncul berupa biaya transportasi, biaya telepon, biaya akomodasi penagihan dll ditanggung oleh pihak kedua (II).

Dalam akad tersebut BMT Pahlawan akan memberikan denda kepada nasabah sebesar $0.2 \%$ perhari dari saldo tunggakan apabila angsuran lewat dari tanggal yang telah disepakati tanpa memiliki alasan yang jelas. Pada akad tersebut keterangan besaran denda guna memberikan peringatan kepada nasabah agar melakukan disiplin dalam membayar angsuran. Akan tetapi seperti yang dikatakan 
sebelumnya bahwa angsuran tersebut tidak langsung dikenakan oleh nasabah yang masih memiliki itikad yang baik. Jumlah denda yang diberikan nasabah tersebut harus sesuai dengan kesepakatan dan sesuai dengan kemampuan dari nasabah.

\section{Dana yang berasal dari denda diperuntukkan sebagai dana sosial.}

Sebagaimana dalam akad BMT Pahlawan bahwa denda akan disalurkan ke Baitul Maal BMT Pahlawan. Bidang baitul maal BMT Pahlawan ini mengelola kegiatan seperti zakat, infaq, sedekah dan wakaf dari aghnia' dan akan disalurkan kepada dhuafa serta 8 golongan asnaf sesuai al-Qur'an surat Taubah ayat 60 selain itu penyeluran lain untuk kegiatan sosial seperti bantuan beasiswa, pembangunan masjid,dll.

Dari penjelasan diatas dapat dianalisis bahwa bmt Pahlawan Tulungagung sudah sangat sesuai dalam menerapkan praktik denda sesuai dengan fatwa Dewan SyariahNasional-Majlis Ulama Indonesia dibolehkannya denda bagi nasabah yang mampu tetapi menunda-nunda dalam membayar hutangnya yang bertujuan agar nasabah tidak melalaikan kewajibannya dan lebih disiplin untuk membayar hutangnya.

Jika diamati dalam fatwa tersebut masih banyak ayat al-Qur'an, al-Hadits, maupun pendapat ulama yang dikutip DSN-MUI sebagai rujukan, semuanya masih bersifat global. Baiksecara tersurat maupun tersirat, belum ada yang membahas denda

keterlambatannya (Abdurrohman, 1974). Hadits-hadits yang dijadikan rujukan oleh DSNMUI pun juga masih bersifatglobal. Hanya saja ada hadits yang sekiranya lebih spesifik untuk dijadikanrujukan oleh DSN MUI untuk membolehkan denda keterlambatan dalam pembayaran dalam angsuran pembiayaan Bai' Bitsaman Ajil, yaitu hadits. Hadits ini menyebutkan bahwaorang yang menunda-nunda membayar hutang padahal ia mampu, dapatdikenakan sanksi.

Demikian halnya dengan pendapat para ulama yang dijadikan rujukan olehDSN MUI tentang pengenaan denda keterlambatan pembayaran dalam akad jual beli. Justru ijtihad lah yang paling dominan dijadikan pijakan oleh DSN MUI.Oleh karena itu, tidak ditemukan ayat al-Qur'an, hadits, maupun pendapatulama yang dijadikan rujukan oleh DSN MUI yang membolehkan pengenaandenda keterlambatan. Justru sebaliknya, diperintahkan untuk memberikankelonggaran bagi orang yang kesulitan membayar hutang.

Memang ada salah satu hadits yang dijadikan rujukan oleh DSN MUImenyatakan bahwa orang yang menunda-nunda pembayaran utang padahal ia mampu, boleh dikenakan sanksi (Burhanuddin, 2010). Namun, tentu saja sanksi itu tidak bolehberbentuk denda. Sebab, denda merupakan bagian dari "menarik manfaat darihutang" yang dalam hadits lain termasuk riba.

Jika ada alasan yang diakui secara syar'i, maka alasan tersebut mengugurkan kewajiban membayar denda sampai alasan tersebut berakhir. Jika nominal denda terlalu berlebihan menurut konsesus masyarakat setempat, sehingga tujuan 
pokoknya adalah ancaman dengan denda, dan nominal tersebut jauh dari tuntutan kaidah syariat, maka denda tersebut wajib dikembalikan kepada jumlah nominal yang adil, sesuai dengan besarnya keuntungan yang hilang atau besarnya kerugian yang terjadi. Jika nilai nominal tidak kunjung disepakati, maka denda dikembalikan kepada keputusan pengadilan, setelah mendengarkan saran dari pakar dalam bidangnya, dalam rangka melaksanakan firman Allah, yaitu surat an-Nisa'. Jadi, anggapan sebagian orang bahwa syarth jaza'i secara mutlak itu mengandung unsur riba nasi'ah adalah anggapan yang tidak benar. Anggapan ini tidaklah salahjika ditujukan untuk transaksi-transaksi yang pada asalnya adalah utangpiutang, semisal jual-beli kredit dan transaksi salam.

Tabel 1.1 Kesesuaian Denda di BMT Pahlawan Tulungagung dengan Ketentuan dalam Fatwa DSN-MUI No. 17/DSNMUI/IX/2000

\begin{tabular}{llll}
\hline No & Ketentuan & Penerapan & Ket \\
\hline 1 & Sanksi yang & BMT & Sesuai \\
& disebut & Pahlawan & \\
dalam fatwa & memberikan & \\
ini adalah & denda & \\
sanksi yang & kepada \\
dikenakan & nasabah & \\
LKS kepada & yang mampu \\
nasabah & dalam \\
yang & membayar & \\
mampu & angsuran & \\
membayar, & akan tetapi & \\
tetapi & menunda- \\
menunda- & nunda \\
nunda & sampai batas & \\
pembayaran & waktu yang \\
dengan & telah \\
\hline
\end{tabular}

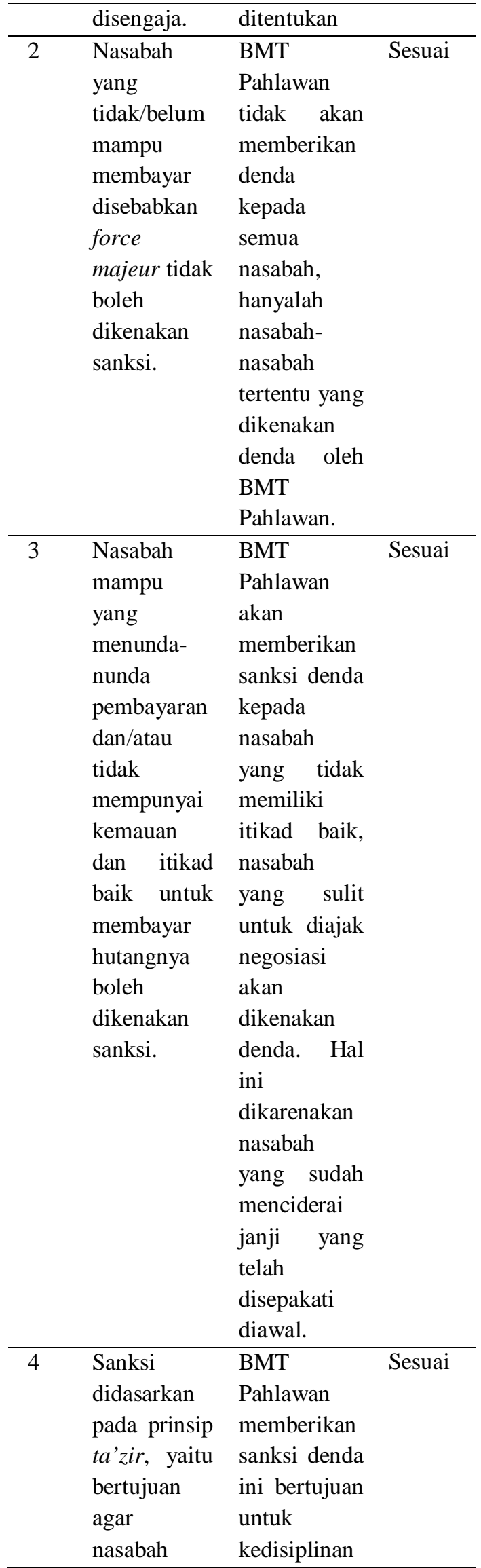




\begin{tabular}{|c|c|c|}
\hline & $\begin{array}{l}\text { lebih } \\
\text { disiplin } \\
\text { dalam } \\
\text { melaksanak } \\
\text { an } \\
\text { kewajibanny } \\
\text { a. }\end{array}$ & $\begin{array}{l}\text { nasabah } \\
\text { membayar } \\
\text { angsuran. } \\
\text { BMT } \\
\text { Pahlawan } \\
\text { tidak } \\
\text { memaksa } \\
\text { atas denda } \\
\text { yang telah } \\
\text { diberikan } \\
\text { kepada } \\
\text { nasabah. }\end{array}$ \\
\hline 5 & $\begin{array}{l}\text { Sanksi dapat } \\
\text { berupa } \\
\text { denda } \\
\text { sejumlah } \\
\text { uang yang } \\
\text { besarnya } \\
\text { ditentukan } \\
\text { atas dasar } \\
\text { kesepakatan } \\
\text { dan dibuat } \\
\text { saat akad } \\
\text { ditandatanga } \\
\text { ni. }\end{array}$ & $\begin{array}{l}\text { Jumlah } \\
\text { denda yang } \\
\text { diberikan } \\
\text { nasabah } \\
\text { tersebut } \\
\text { sesuai } \\
\text { dengan } \\
\text { kesepakatan } \\
\text { dan sesuai } \\
\text { dengan } \\
\text { kemampuan } \\
\text { dari nasabah. }\end{array}$ \\
\hline 6 & $\begin{array}{l}\text { Dana yang } \\
\text { berasal dari } \\
\text { denda } \\
\text { diperuntukk } \\
\text { an sebagai } \\
\text { dana sosial. }\end{array}$ & $\begin{array}{l}\text { Sebagaiman } \\
\text { a dalam akad } \\
\text { BMT } \\
\text { Pahlawan } \\
\text { bahwa denda } \\
\text { akan } \\
\text { disalurkan } \\
\text { ke Baitul } \\
\text { Maal BMT } \\
\text { Pahlawan. }\end{array}$ \\
\hline
\end{tabular}

\section{Penutup}

Dari hasil analisa dan pembahasan diatas dapat disimpulkan bahwa praktik penerapan denda di BMT Pahlawan adalah sebagai berikut:

1. Denda yang dikenakan oleh BMT Pahlawan atas keterlambatan membayar oleh nasabah yang mampu sebesar $0,2 \%$ perhari. Denda tersebut dikenakan oleh nasabah tertentu apabila tidak memiliki itikad baik untuk membayar. Untuk nasabah yang masih memiliki itikat baik membayar denda akan dihapuskan, serta akan dimunculkan kembali saat nasabah tersebut mengalami cidera janji.

2. Penerapan denda pada pembiayaan Bai' Bitsaman Ajil di BMT Pahlawan Tulungagung sudah sesuai dengan Fatwa DSN No. 17/DSN-MUI/IX/2000. Pada penerapannya denda tersebut dikenakan atas nasabah yang mampu dan menunda-nunda pembayaran serta nasabah yang tidak memiliki itikad baik dalam melunasi angusran pembayarannya.

3. Dana yang diperoleh BMT Pahlawan disalurkan kepada bidang Baitul Maal. Bidang baitul maal BMT Pahlawan ini mengelola kegiatan seperti zakat, infaq, sedekah dan wakaf dari aghnia' dan akan disalurkan kepada dhuafa serta 8 golongan asnaf sesuai al-Qur'an surat Taubah ayat 60 selain itu penyeluran lain untuk kegiatan sosial seperti bantuan beasiswa, pembangunan masjid, dll.

\begin{tabular}{llr}
\multicolumn{2}{c}{ Tanpa } & \multicolumn{2}{c}{ mengurangi rasa } \\
hormat kami & kepada & segenap \\
manajemen & BMT & Pahlawan
\end{tabular}


Tulungagung, izinkan peneliti memberikan rekomendasi untuk perbaikan lembaga keuangan BMT Pahlawan Tulungagung:

1. BMT Pahlawan merupakan lembaga keuangan terbesar di Tulungagung, seharusnya menjadi panutan oleh BMTBMT lain untuk menerapkan denda sesuai dengan prinsip syariah, Sehingga sosialisasi kepada jaringan-Jaringan BMT Perlu untuk dilakukan agar saling bersinergi.

2. Mempertahankan penerapan denda berdasarkan prinsip syariah (sesuai dengan Fatwa DSN-MUI) yang telah dibangun agar terus berjalan sesuai dengan syariat Islam.

3. Menggunakan dana yang diperoleh tidak untuk kegiatan sosial bersifat konsumtif, tapi juga digunakan untuk kegiatan sosial yang bersifat produktif seperti wakat tunai, pembiayaan qordhul hasan, pembiayaan produktif, agar terjadi pemerataan penggunaan dana dari uang denda.

\section{Daftar Pustaka}

Abdurahman, Asmuni.1974. AlQawaidul al-Fiqhiyah. Yogyakarta: Syari'ah IAIN Sunan Kalijaga.

Basrowi \& Suwandi. 2008.Memahami Penelitian Kualitatif. Jakarta: PT. RENEKA CIPTA.

Burhanuddin. 2010. Aspek Hukum Lembaga Keuangan Syari'ah. Yogyakarta: Graha Ilmu.

Djazuli, A. 2002. Lembaga-lembaga Perekonomian Umat; Sebuah
Pengenalan. Jakarta:

RajaGrafindo Persada.

Fatwa Dewan Syariah Nasional Majelis Ulama Indonesia No. 17/DSN-MUI/IX/2000

Irfan, M. Nurul dan Masyofah. 2013. Fiqh Jinayah, Jakarta : AMZAH.

Karim, Adiwarman A. 2001. Ekonomi Islam; Suatu Kajian

Kontemporer. Jakarta, Gema Insani Press.

Laporan Perkembangan BMT Pahlawan Tulungagung Tahun Buku 2018

Moleong,Lexy J. 1998. Metode Penelitian Kualitatif. Bandung: Remaja Rosdakarya.

Munawwir, Ahmad Warson. 1987. Kamus Al-Munawwir ArabIndonesia, (Surabaya: Pustaka Progressif.

Sam, H.M. Ichwan et.al.2003. Himpunan Fatwa Dewan Syariah Nasional MUI. Jakarta, (Dewan Syari'ah Nasional Majlis Ulama Indonesia). edisi ke-2.

Syamsuir, Lembaga Keuangan Islam Non Bank, Jurnal Islamika: Vol 15 No. 01 April 2017

Yandiato. 2001.Kamus Umum Bahasa Indonesia. Bandung: $\mathrm{M} 2 \mathrm{~S}$. 